\title{
POSSIBLE TRACES OF FINNIC INFLUENCE IN LATVIAN SUBDIALECT PHONETICS AND MORPHOLOGY
}

\author{
Anna Stafecka \\ University of Latvia, Latvian Language Institute, LV \\ anna.stafecka@lu.lv
}

\begin{abstract}
This article discusses areas observed on geolinguistic maps showing Finnic or Finnic-like features in Latvian subdialects possibly resulting from Finnic influence. The Latvian dialect material analysed for this study shows that several such areas can be identified based on their phonetics and morphology: the Livonic dialect, the Selonic subdialects, certain Selonic subdialects on both banks of the Daugava River, certain subdialects in the former Leivu territory in northeastern Latvia near Alūksne and Gulbene, and a few subdialects in Zemgale near Bauska and Vecsaule where the Krevin Votians were settled. The shortening of word endings and generalisation of third-person verb forms is also quite regularly encountered in the subdialects spoken around Preili in Latgale. The least amount of language material is available about the Ludza Estonians or Lutsis who lived in eastern Latgale where their influence is seen in the tone system of the local subdialects.
\end{abstract}

Keywords: Latvian dialects, Finnic languages, dialectology, geolinguistics, language contact.

DOI: https://doi.org/10.12697/jeful.2021.12.2.03

\section{Introduction}

This article describes possible Finnic influence on the phonetics and morphology of Latvian subdialects. As Finnic influence is best preserved in the Livonic dialect of Latvian and similar language features are also encountered in other Latvian dialects, this article discusses areas observed on geolinguistic maps showing unique groups of shared features in Latvian subdialects, which could be explained by possible Finnic influence. This analysis utilises the maps and comments found in the Latviešu valodas dialektu atlants (Atlas of Latvian Dialects) volume on phonetics by Dr. philol. Alberts Sarkanis. It also uses the maps and comments of the atlas's recently published first volume on morphology 
(LVDA 2021). The editor of this volume was Dr. philol. Anna Stafecka. The second volume is in preparation.

The Latvian dialect material analysed for this study shows that several such areas can be identified based on their phonetics and morphology: the Livonic dialect, the Selonic subdialects, certain Selonic subdialects on the right (Aizkraukle, Skrīveri, Pḷavinas, etc.) and left banks (Daudzese, Sece, etc.) of the Daugava River as well as in some subdialects in the former Leivu territory in northeastern Latvia near Alūksne and Gulbene (Ilzene, Lejasciems, Kalncempji, etc.), and a few subdialects in Zemgale near Bauska and Vecsaule where the Krevin Votians were settled. The least amount of language material is available about the Ludza Estonians or Lutsis who lived in eastern Latgale where their influence has been identified in the tone system of the local subdialects. The shortening of word endings as well as several parallels to Livonic dialect verb forms, for example, generalisation of thirdperson verb forms to other persons, is also quite regularly encountered in the subdialects spoken around Preiḷi (in Galēni, Rudzēti, less often in Aizkalne and Vārkava).

This article has the following structure. Section 2 describes earlier research into Finnic influence in Latvian. Section 3 gives an overview of known Finnic influence and Finnic-like features in Latvian dialects, while Section 4 looks specifically at the influence of the South Estonian Leivu and Lutsi varieties on Latvian. Section 5 presents a series of geolinguistic maps to help visualise the location and extent of certain Finnic or Finnic-like features in Latvian. Section 6 expands on this by providing a more in-depth description of these features. Section 7 concludes this article by presenting a list of areas in Latvia showing Finnic or Finnic-like features.

\section{Earlier research on Finnic influence in Latvian}

Though Latvian and its neighbours - Livonian and Estonian - belong to different language families, contact among them has been close and with a long history. Research into this contact has been ongoing for more than a century. As noted by Latvian linguist Ojārs Bušs, lexical borrowings from Finnic languages, primarily from Estonian and Livonian, have been studied for more than 100 years (Bušs 2009a: 31). They have been 
the subject of several monographs of which the most well-known is the study by Danish linguist Vilhelm Thomsen (Thomsen 1890), in which he mentions, among other things, more than 180 borrowings from the Finnic languages. Important contributions to the study of Baltic and Finnic languages have been made by Lauri Kettunen (Kettunen 1938), Jānis Endzelīns (Endzelīns 1970; ME, EH), Karl Aben (Aben 1957), Valdis Juris Zeps (Zeps 1962), Eberhard Winkler (Winkler 1997), Lembit Vaba (Vaba 1997), etc. The following Latvian linguists should also be mentioned in this regard: Marta Rudzīte, Silvija Raǵe, Ojārs Bušs, Antons Breidaks, Benita Laumane, Elga Kagaine, Kersti Boiko, etc. (for more on this see Bušs 2009b: 10-11). In recent years, Uldis Balodis has studied the Lutsis (Balodis 2015; 2019; 2020).

Research into mutual influence between Latvian and the Finnic languages has focused mostly on lexical borrowings - Baltic and Finnic linguists have primarily studied vocabulary and toponyms borrowed from Livonian and Estonian, while focusing less on grammatical structure and word formation, as grammatical change occurs relatively slowly (Rudzìte 1958: 145-146). Brigita Bušmane has studied the distribution of Finnic-origin vocabulary in Latvian subdialects from a geolinguistic perspective (Bušmane 2000), while Anna Stafecka has studied this in Latvian and Lithuanian subdialects (Stafecka 2014).

The characteristic features, phonetics, and morphology of the Livonic dialects of both Kurzeme and Vidzeme are examined in M. Rudzìte's book Latviešu dialektologija (Latvian Dialectology), which provides a detailed description of the vocalism and consonantism of the Livonic dialects giving special attention to shortening of long vowels, syllable changes in suffixes as well as features of compound formation and verb conjugation (Rudzite 1964: 149-255). Detailed studies of the phonetics and morphology of certain Livonic subdialects can be found in various subdialect descriptions. An impressive number of Livonic subdialect descriptions has been published in the Filologu biedrības raksti (Proceedings of the Society of Philologists; 1920-1940). A number of studies on the Livonic subdialects were published beginning in the second half of the 20th century (Putniņš 1985, Krautmane-Lohmatkina 2002, Dravniece 2008, Draviņš \& Rūķe 1956, 1958). A dictionary of the Vidzeme Livonic Vainiži subdialect has also been published (Ādamsons \& Kagaine 2000). 


\section{Finnic influence in Latvian dialects and subdialects}

The Latvian language formed as a result of the merging of Baltic tribes in the 10th-12th centuries. Traces of these tribes' languages can still be found in the more than 500 Latvian subdialects (in Latvian linguistics, a subdialect is traditionally considered to be the language variety spoken within the territory of one civil parish (Latvian: pagasts) according to the administrative boundaries of 1939). These subdialects are traditionally grouped into three dialects: Central (also Middle), Livonic (also Livonian, Livonian-influenced, or Livonianised), and High Latvian (see Figure 1). The Livonic dialect has been influenced by the Livonian language more than any other Latvian dialect (Rudzite 1964: 149), though Livonian influence often extends beyond the boundaries of this dialect.

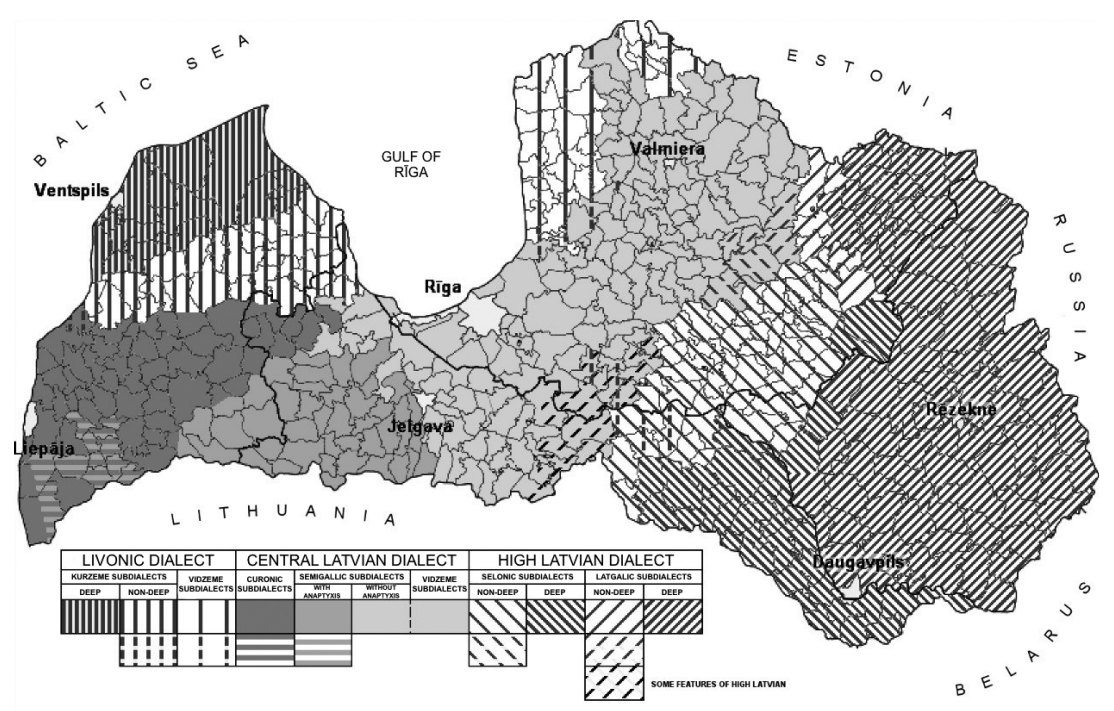

Figure 1. The Dialects of Latvian (The digital version of this map was created by L. Markus-Narvila based on the Latvian dialect map in Rudzìte 1993).

Several phonetic changes are attributable to Finnic and especially Livonian influence. Foremost among these is first syllable stress and also, for example, au > ou (saule > soul 'sun'); however, Jānis Endzelīns considered attribution of this change to foreign influence as hypothetical, because it is not always possible to determine whether this sound change arose as a result of influence or independently (Endzelīns 1970: 8). 
Other examples include the sound change ${ }^{1} \bar{e}>e i$, as in, péc $>$ peic 'after' (Endzelīns 1951: 138-139), sound changes affecting long vowels and the diphthongs $i e$ and $u o$ in suffixes and final syllables (including in noun case endings), and the loss of short vowels in final syllables. Features considered characteristic of the Livonic dialect include, for example, the loss of feminine gender and the generalisation of the third person in conjugation.

The Livonic dialect is spoken in northern Kurzeme and northwestern Vidzeme. The subdialects spoken near Rūjiena are also similar to these. The Livonic subdialects are divided into two groups: the Vidzeme Livonic subdialects and the Kurzeme Livonic subdialects - also called the Tamian (tāmnieku) subdialects.

The Kurzeme and Vidzeme Livonic subdialects also differ from each other and these differences are due to historical circumstances. Each of these groups has a different group of Latvian subdialects at its foundation, which interacted with Livonian, but not in the same ways. The Kurzeme Livonic subdialects came about as a result of contact between the Latvianised Curonian language and the Kurzeme Livonian language, while in Vidzeme, the Vidzeme Livonian language was in contact with the Semigallian-influenced Central dialect of Latvian spoken in Vidzeme (see Rudzīte 1964: 151-152). M. Rudzīte also catalogued the unique features characterising both groups of Livonic subdialects (Rudzìte 1964: 149-255), for example, the Standard Latvian (henceforth, SL) third-person pronoun viňs is viš in the Tamian subdialects, but vin,č in the Vidzeme Livonic subdialects. The Kurzeme Livonic subdialects are characterised by certain features also found in the Curonic subdialects of the Central dialect. The Vidzeme Livonic subdialects, on the other hand, are characterised by certain unique changes to final syllables, for example, the shift of the vowel $e$ to a (tupal < tupele 'slipper; clog', evval < èvele 'plane'), $e$ or $a$ are used in place of $i e$ in suffixes (saimneks < saimnieks 'master; landlord, owner', latvaš < latvieši 'Latvians'); the plural dative pronouns mumsim, jumsim are encountered after prepositions; the preposition iekš 'in' is also typical (iekš pur vid 'in the middle of the swamp' (SL purva vidū), iekš zēm 'in the land' (SL zemē)).

1 According to Latvian linguistic practice, $e$ and $\bar{e}$ denote Latvian "narrow e" - [e] and [e:], while $e$ and $\bar{e}$ denote Latvian "broad e" $-[æ]$ and [æ:]. 
Compound formation is also one of the most productive word formation methods in the Livonic subdialects, for example, vidnakt 'midnight', ābellkuoks 'apple tree', mellanuogs 'bilberries', upsmutt 'river mouth', also word formation models using -pakala 'hind part' and -apakša 'lower part' (also -apuža), for example, mežpakal,a 'area behind a forest', kalnapuža 'foot of a hill', kājapuža 'sole of a foot', malkielpakal, 'area behind a pile of firewood', auspakala 'area behind one's ear', mugurpakala 'back (of something); rear area', which may be due to Finnic influence. Linguist Elga Kagaine has analysed the grammatical features, compound formation, and word formation models using -apakša (-apuža, -apukša, -apaža), -pakalı in the subdialects of northern Vidzeme. She emphasises that these models are dominant not only in the Livonic dialect area, but are also found in the subdialects of the Central dialect in Vidzeme, have been fully incorporated into the Latvian subdialect word formation system and have also largely limited the productivity of the Baltic model (derivations with $p a$ - and aiz-) (Kagaine 2008: 619-627). Silvija Rage (2003: 269) also notes possible influence on syntax seen in disagreement among sentence constituents, for example, gulèt gripā 'to have the flu' (SL gulēt, slimot ar gripu), salma jumts 'straw roof' (SL salmu jumts), ievest sienus 'to bring harvested hay into the barn' (SL ievest sienu), etc.; the locative of purpose iet govīs 'to go after cows' (SL iet pēc govìm).

Finnic influence can also be found in Latvian subdialects elsewhere in Latvia. J. Endzelīns observes that the shortening of final syllables in infinitives, which is characteristic of the Livonic subdialects, is also found in the Selonic subdialects of Cesvaine, Patkule, Lazdona, Prauliena, Pḷaviņas, Sarkaṇi (Endzelīns 1951: 69) and also in other High Latvian subdialects (Alūksne, Lejasciems, and others.), though suffixes are shortened most often in Skriveri, Daudzese, and Sece where the Livonians may have lived in the past (Endzelīns 1951: 70). The maps, dialect material, and other studies published in the Latviešu valodas dialektu atlants (Atlas of Latvian Dialects) confirms these features.

Compounds with an initial nominative component have been recorded in certain Vidzeme Selonic subdialects, for example, grāvsmala (grẩus'molå) 'side of a ditch' in Aduliena, plavazāle (plouå.zálè) 'meadow grass' in Meirāni, liepaziedus (l'iepa.ziéd"s) 'linden blossoms' in Saikava (Poiša 1999: 106). This type of compound is considered to have developed due to Finnic influence as well as the aforementioned 
word formation model using -pakala, which has also been recorded in the Vidzeme Selonic subdialect region, e.g., stòlpokåla 'area behind a stall', klèccpokålı 'area behind a barn' (for more see Poiša 1999: 106107). M. Poiša has also identified still other features explainable by Finnic influence, e.g., a masculine form tas 'that' is used to refer to a feminine subject in tas $i$ gimenes lieta 'that is a family matter' (SL $t \bar{a}$ ir gimenes lieta) in Cesvaine (Poiša 1999: 108), the masculine pronoun tas is used to refer to feminine nouns in a:dolas ta miza 'that bark is separating' (SL atdalās tā miza) in Aduliena and săkå tas moâia dẹ:kt 'that house began to burn' (SL sāka tā māja degt) in Dzelzava (Poiša 1999: 108).

\section{Leivu and Lutsi influence in Latvian}

The Leivus who were migrants from southeastern Estonia lived near Alūksne and Gulbene in northeastern Latvia. The Lejasciems Latvian subdialect has been described in considerable detail by linguist Daina Zemzare (Zemzare 2011) giving attention not only to vocabulary and toponymy, but also phonetics and morphology. D. Zemzare mentions shortening of long vowels as well as vowel loss in suffixes, also the presence of certain suffixes of Estonian origin and other features (Zemzare 2011: 109-114). At present, there are many place names of Finno-Ugric origin in this region, especially in Lejasciems - where home and village names with Finno-Ugric roots are already found in the 1630 revision lists - also in Ilzene and Kalniena (for more see Jansons 1962: 199-204; also, Balode 2008: 11). In writing about Finno-Ugric place names near Gulbene, A. Jansons hypothesises that these place names may testify not only to the presence of immigrant Estonians, but also of other more ancient Finno-Ugric populations that lived mixed with the Latgalians.

There are few traces of Lutsi influence on surrounding Latvian subdialects with the exception of some lexical borrowings, most of which also occur in Standard Latvian. Linguist Antons Breidaks mentions several borrowings typical of Latgalic subdialects, for example, endelèties (end'el̦at'iss') 'to argue, fight', kete 'left hand', kugre 'crucian carp', sugulis (suguls) 'colt' as well as several Finnic-origin toponyms, for example, Paideri (village), Pylda (village), Raibakozy (village), 
Rauzu azars (lake), Soidu azars (lake) (Brejdak 2007 [1970]: 254-255). The eastern Latgale Latvian subdialects have two tones: falling and broken. However, A. Breidaks mentions several subdialects near Ludza where only one tone is observed in the speech of Latvianised Lutsi descendants. This tone, which is similar to the stretched tone of the Central dialect, is the reason that people in this area say of the Estonians and their speech that igauni velk - the Estonians drawl (Brejdak 2007 [1970]: 253). Thus, the broken and falling tones have combined into a single - falling - tone in the speech of Latvianised Estonians (for more see Breidaks 2007 [1972]: 30).

\section{Visualising Finnic influence with geolinguistic maps}

The distribution of different dialect features is best depicted using geolinguistic maps. The Livonic dialect was already an object of study at the end of the 19th century. August Bielenstein devotes one map (Figure 2) to depicting dialect differences in the atlas he published in 1892 (Bielenstein 1892).

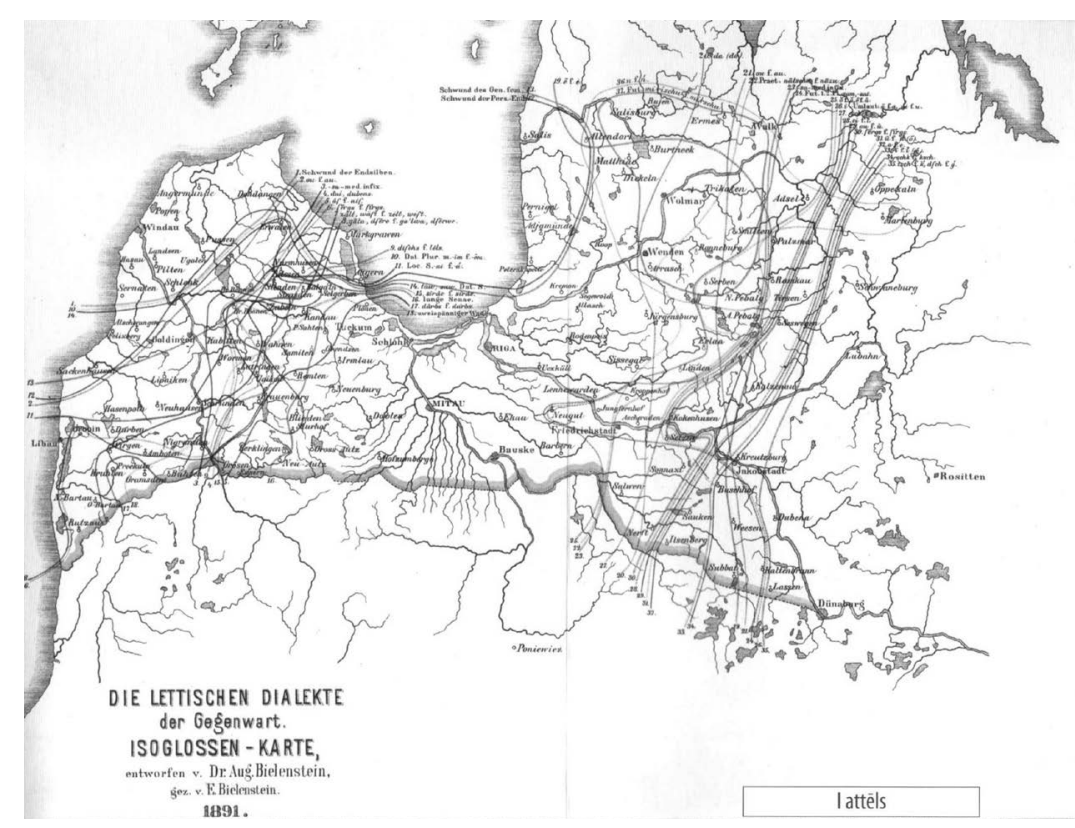

Figure 2. A. Bielenstein's isogloss map published in 1892. 
33 isoglosses are used to show the distribution of primarily phonetic and morphological features across Latvian subdialects. Groups of isoglosses show dialect and even subdialect group boundaries. Several isoglosses are devoted to the Kurzeme Livonic subdialects, for example, isogloss 1 shows the loss of the final syllable, isogloss 2 shows $a u>o u$, isogloss 12 shows the loss of person endings, isogloss 13 shows the loss of the feminine gender, etc.

Nearly 50 years later, linguist Velta Rūķe turned her attention to mapping the features of the Livonic dialect. In 1940, she published three maps with extensive comments of the Livonic dialect regions of Kurzeme and Vidzeme (Rūķe 2017 [1940]: 405-461), which show the phonetic and morphological features of these subdialects. The northern Kurzeme map uses 13 isoglosses to show phonetic differences (Figure 3) such as $a u>o u, \bar{o}$ (isogloss 3), the debitive with $j \tilde{a}-$, jâ-, or $j a$ - (isogloss 5), the diminutive with -iñš, -î̌s, -ǐ̌s (isogloss 6), the thirdperson pronoun vî̌s, vǐs 'he' (SL viņ̌s) (isogloss 7), the first-person singular pronouns es and ęs (isogloss 10), the first-person plural pronouns $m \tilde{e} s$ and $m \tilde{e} s$.

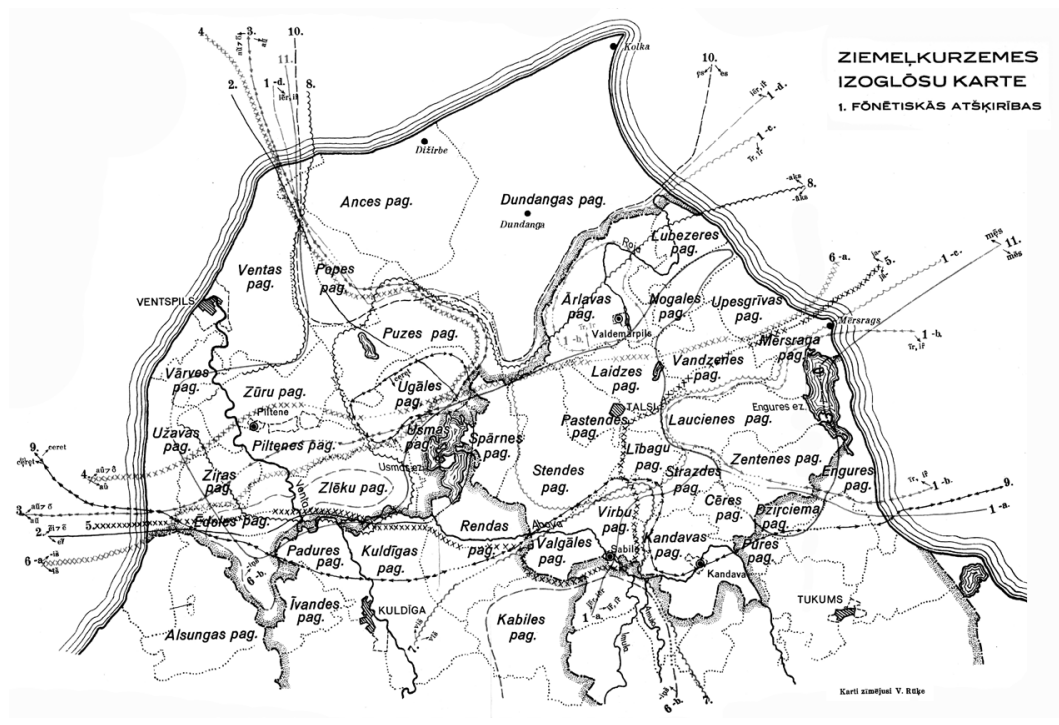

Figure 3. V. Rūḳe. Northern Kurzeme isogloss map. Phonetic differences. 
16 isoglosses are used to show morphological differences (Figure 4), for example, isogloss 1 shows the shift of the ending -šan[a] to $-\check{s} e, n$, 8 isoglosses are devoted to the dative and locative endings of iio- and iia-stem nouns. Isoglosses 10-15 show the distribution of the prepositions pie, nuo, aiz and the corresponding prefixes pie-, nuo-, aiz-, while isogloss 16 shows the distribution of the present tense $\bar{a}$ - and $\bar{o}$-stem reflexive verb endings.

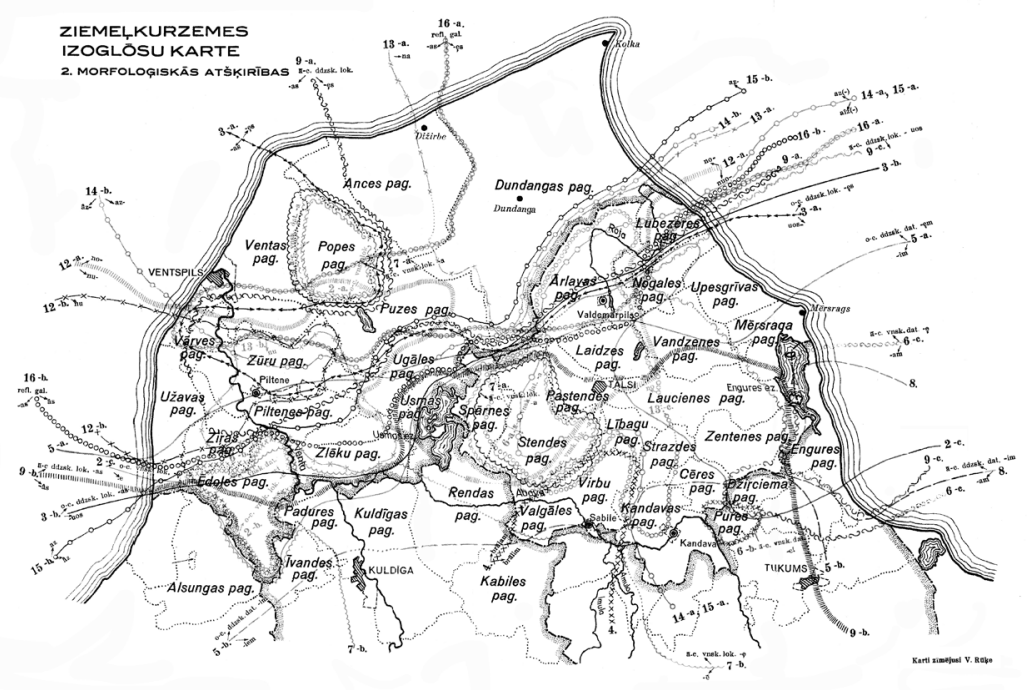

Figure 4. V. Rūķe. Northern Kurzeme isogloss map. Morphological differences.

V. Rūķe's third map is devoted to the western Vidzeme region, i.e., to the Vidzeme Livonic subdialects (Figure 5). 13 isoglosses are used on this map to show phonetic and morphological differences: tone in the verbs iet 'to go', nemt 'to take' (isogloss 1), the pronunciation ([e] vs. $[æ])$ of the vowel $e$ in monosyllabic infinitives, the loss of $j$ after labials. The other 10 isoglosses show the morphological differences of these subdialects: the diminutive suffix -iňs (isogloss 4), the singular locative and plural dative and locative endings of iio-stem nouns (isoglosses 5-7), feminine plural $u$-stem forms (isogloss 9), the separation between the present tense uoja- and aja-verb stems (isogloss 11), the future tense forms of the verbs $n \bar{a} k t$ 'to come', mirt 'to die' (nāas $\bar{\imath} s, m i r \bar{\imath} s, n \bar{a} k s$, mirs) (isogloss 12), the use of the supine (isogloss 13). 


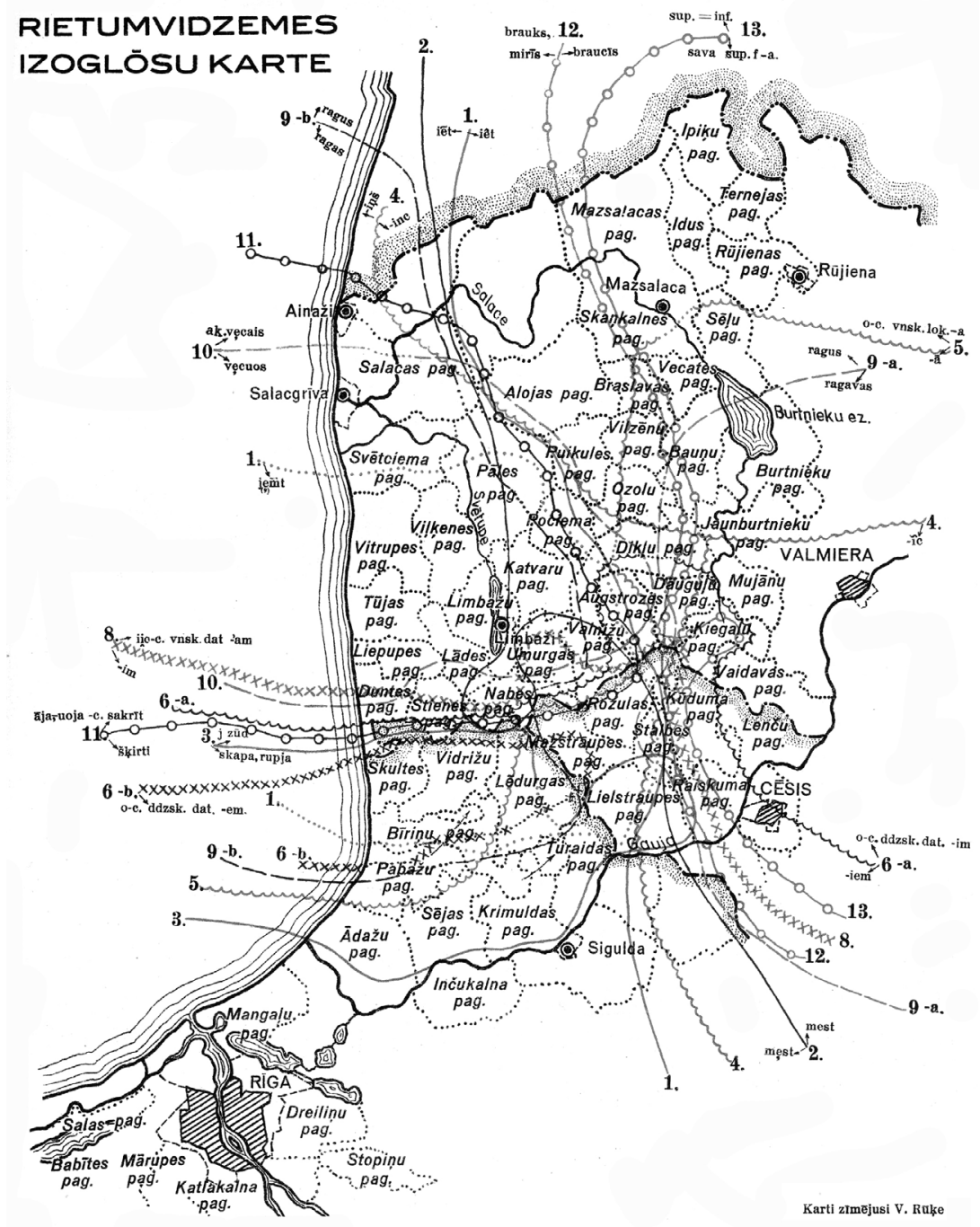

Figure 5. V. Rūķe. Western Vidzeme isogloss map. 


\section{Examples of Finnic influence and Finnic-like features in Latvian subdialects}

The phonetics volume of the Latviešu valodas dialektu atlants (Atlas of Latvian Dialects) was published in 2013 and was compiled by Dr. philol. Alberts Sarkanis (LVDA 2013). The maps of this atlas show Finnic influence not only in the Livonic dialect, but also in the High Latvian Selonic subdialect region, for example, secondary lengthening of syllable tone following voiced consonants $d \hat{a} b(a), k \hat{a} z(a)$, Selonic subdialect: kôza, Latgalic subdialect: $k o ̀ z(a)$ (Map 6), the palatal umlaut ue or ue of the diphthong uo in the words kuoks, uozuols, ruoze, and others (Map 54), shortening of the vowel $\bar{l}$ in the suffix $\bar{\imath} b$ - barib, labib (Map 67), umlaut of vowel $\bar{a}$ is also encountered in this region (Map 56). $e>\rho$, or $\underline{e}$ has been recorded in the ordinal numeral desmitais 'tenth' in a compact area of the Kurzeme Livonic subdialect region, less often in the Vidzeme Livonic subdialects, and mostly in the Vidzeme Selonic subdialects (Map 41), similarly $\bar{a}>\bar{e}$ occurs in the word pārsla $>$ pêrsla 'flake' in the Kurzeme Livonic subdialects and in a portion of the Vidzeme Central and Selonic subdialects (Map 17), the diphthong au>ou (soule 'sun', broukt 'to drive'), which is characteristic of the Livonic dialect, is also found in a compact region in Vidzeme, less often in the Zemgale Selonic subdialects, and also in the northern Vidzeme Central subdialects as well as in a few Latgalic subdialects in Vidzeme and northern Latgale (Map 51). The shift of $a$ to $e$ in stressed syllables following tautosyllabic $r$, for example, serkans 'red', serrma 'hoarfrost', has been recorded in the Vidzeme Livonic subdialects as well as in the Selonic and Semigallic subdialects near Bauska and Vecsaule, i.e., the territory historically inhabited by the Krevin Votians (Map 14). The shift $\bar{e}>\bar{a}$, less often $\bar{e}$, in the word $v \bar{e} l$ 'still, yet' has been identified in the Vidzeme Selonic and Vidzeme Latgalic subdialects near Alūksne and Gulbene, i.e., the former Leivu territory (Map 45).

Shortening of the vowel $\bar{a}$ in the infinitive runat 'to speak' (Map 79) and in the infinitive ending -ināt in dedzinat 'to burn', èdinat 'to feed' (Map 80); and shortening of the vowel $\bar{e}$ in the infinitive ending -èt in tecet 'to flow, trickle', redzet 'to see', sēdet 'to sit' (Map 81) are found in the Vidzeme Livonic subdialects as well as in a few Selonic subdialects on the right bank of the Daugava River. 
Many phonetic features are also found in the recently published first morphology volume (LVDA 2021) as well as the second morphology volume (still in preparation) of the Latviešu valodas dialektu atlants (Atlas of Latvian Dialects). Just as in the Phonetics volume, the Livonic dialect region can be identified in the Morphology volume material, which shows not only characteristic morphological, but also phonetic, features of this dialect not included in the $A L D$ Phonetics volume. Using the materials collected for the Morphology volume stored at the University of Latvia Latvian Language Institute, the phonetic and morphological features typical of the Livonic subdialects also occurring in other Latvian subdialects, are examined below. However, it should be noted that the subdialect material collected for the $A L D$ is quite varied, therefore, it can provide only an approximation of possible Finnic influence or the traces of this influence, which have been preserved in Latvian subdialects.

Shortening or loss of case endings is a feature of noun declension typical not only of the Livonic subdialects, but also encountered in other parts of Latvia. Below are some examples of these types of changes.

The loss of the case ending in the io-stem singular accusative and instrumental common form, for example, cel, cēel, vēj, (cf. SL cel̦u 'road (AccSg, InstSg)', vēju 'wind (AccSg, InstSg)'), which is encountered over a large, compact portion of the Livonic dialect area, but is also recorded in a few subdialects on the right (Skrīveri, Aizkraukle, Plaviñas) and left banks (Daugmale, Rembate, Sece) of the Daugava River as well as in the Zemgale Krevin Votian territory (Vecsaule). The loss of the case ending in the $i \bar{a}$-stem singular accusative and instrumental common form, for example, gal (SL gallu 'meat (AccSg, InstSg)') is found in the Livonic dialect and in several Selonic subdialects on both banks of the Daugava River (Jumurda, Jumprava, Skrīveri, Sece).

The $a$-stem singular dative ending change $a i>e i$, as in for example, lapei (SL lapai 'for a leaf'), is found in a few Kurzeme and even fewer Vidzeme Livonic subdialects and has been recorded in Lèdmane, Jumprava, Skrīveri, Dzelzava, Cesvaine, Patkule, Lazdona, Prauliena.

The $\bar{e}$-stem singular dative priede ( $<\mathrm{SL}$ priedei 'for a pine tree') is found in the Kurzeme Livonic subdialects as well as in Skrīveri, Aizkraukle, Daudzese.

$o$-stem singular locative forms showing a shortened vowel in their ending, for example, kuoka 'in a tree' > kuoka, are widespread in 
the Livonic dialect and also found in Aizkraukle, Koknese, Pḷavinas, Daudzese, and Serene. $o$-stem singular locative forms show the vowel change $\bar{a}>\bar{e}$ in their ending, for example, kuoke, which is typical for some Kurzeme Livonic subdialects around Kuldīga and the Curonic subdialects south of Kuldigga; it has also been recorded in Daugmale, Plātere, Jumprava. The sound change $\bar{a}>\bar{e}>e$, for example, kuoke, is frequently encountered in this case ending in the Kurzeme Livonic subdialects, sporadically in the Vidzeme Livonic subdialects, and has also been recorded in Jumprava, Skrīveri, Daudzese, Krustpils.

Similar changes are also seen in the singular locative forms of other stems, for example, the io-stem form vēja 'in the wind' > vēja, which is widespread in the Vidzeme and Kurzeme Livonic subdialects, and is also recorded in Tome, Aizkraukle, Pḷavinas, Daudzese, Sunākste.

The $a$-stem singular locative form, for example, lapa > lape, derived from - $a i$ - which arose as a result of the shortening of the ancient locative ending - $\bar{a} i$ (for more see Rudzìte 1964: 216), is characteristic of the Kurzeme Livonic subdialects and has also been recorded in Skrīveri, Aizkraukle, Koknese as well as in the former Leivu territory - Ilzene and Kalncempji.

The $e$-stem singular locative form with a shortened vowel in its ending, for example, pried $\bar{e}>$ priede, which is found over a large, compact portion of the Livonic dialect area, has also been recorded in a few Selonic subdialects on the right (Jumprava, Skrīveri, Aizkraukle, Koknese, Pḷavinas) and left banks (Tome, Daudzese, Sunākste) of the Daugava River as well as in Birzuli, Dūre, Ilzene.

The $i$-stem singular locative form with a shortened vowel in its ending, for example, naktī > nakti 'in the night', has a similar distribution and is characteristic primarily of the Vidzeme Livonic subdialects and has also been recorded in several Selonic subdialects on the right (Jumprava, Skrīveri, Aizkraukle, Koknese, Pḷavinas) and left banks (Sērene, Elkšni) of the Daugava River, also in Zemgale (Svēte, Tērvete) as well as in Ilzene.

Plural nominative forms with vowel loss in their ending lap 's, siev's (SL lapas 'leaves', sievas 'women') are found in the Livonic subdialects and have also been recorded in Skrīveri, Aizkraukle, Koknese, Pḷaviņas, Sausnēja.

Plural genitive forms without consonant alternation sirdu (SL siržu 'of hearts'), are characteristic of the Livonic subdialects and have 
alsobeen recorded in Liepkalne, Odziena, Kurmene, Sidgunda, Sāviena, Sērene, Daudzese, and Brukna.

A sound change in the $o$-stem plural dative ending, for example, kuokiem > kuokem 'for trees' is characteristic of the Kurzeme Livonic subdialects, less often of the Vidzeme Livonic subdialects, and is also recorded in Koknese and Pḷavinas.

The plural locative ending -os (<-uos), for example, kuokos, kalnos (SL kuokuos 'in trees', kalnuos 'in hills'), which is characteristic primarily of the Vidzeme Livonic subdialect, is also recorded in Skriveri, but the ending -es, which is dominant in the Kurzeme Livonic subdialects, has also been recorded in Skrīveri.

Also, the form kuokes is typical of the Kurzeme Livonic subdialects and has been recorded in Skriveri in Vidzeme, kuokas - widespread in the Kurzeme and Vidzeme Livonic subdialects has also been found in Skrīveri.

The shortening observed in the $a$-stem plural locative endings, for example in lapas, mājas (SL lapās 'in leaves', mājās 'in homes; at home') is typical of the Livonic dialect and has also been recorded in Aizkraukle, Koknese, Pḷavinas as well as in Nereta and Krustpils.

Several Selonic subdialects (Skrīveri, Ābeḷi, Daudzese, Sēlpils) and Ilzene share the plural locative ending -us, for example, kuokus, kalnus.

The iio-stem plural dative and instrumental common form brālęm (SL brāliem 'brothers (DatP1, InstPl)', which is more commonly encountered in the Kurzeme Livonic subdialects, is also recorded in just a few Vidzeme Livonic subdialects as well as in Aizkraukle, Koknese, Pḷavinas. The $e$-stem plural dative and instrumental common form mātem (SL mātēm 'mothers (DatPl, InstPl)') occurs in the Livonic dialect and a few subdialects along the Daugava River.

Adjectives with definite endings are not declined in the same way in all of the Livonic subdialects. These show phonetic differences, for example, shortening, changes in vowel quality, and also morphological changes (for more see Rudzìte 1964: 219-222).

The definite adjective masculine singular nominative form labais 'the good one', baltais 'the white one' is formed in the Vidzeme Livonic dialects using the segment -ja-, for example, baltaš, labaš $(<$ baltajs, labajs). This form has also been sporadically recorded in the Selonic Skriveri subdialect. The variant labeis, balteis, which occurs in a compact area in the Kurzeme Livonic subdialects around Vandzene, 
Zentene, Kuldīga, has also been recorded in Jumprava and Skrīveri as well as in a small compact area around Cesvaine, Patkule.

The definite feminine adjective singular nominative has the corresponding indefinite adjective form laba, balta, which occurs in a compact area within the Vidzeme Livonic subdialect area and has also been recorded in Skrīveri and Aizkraukle as well as in Dūre and Ilzene.

The plural nominative feminine form labas, baltas, which is characteristic of a few of the Vidzeme Livonic subdialects, is also found in Skrīveri, Aizkraukle, Sāviena, Daudzese as well as Panemune in Zemgale.

The masculine plural nominative form labi, balti has not been recorded in the Livonic subdialects, but is found in Lêdmane and Skrīveri as well as in Ilzene and Lejasciems.

Other differences can also be noted. The generalised third-person form which is considered to be one of the most characteristic features of the Livonic dialect, also occurs sporadically in the Selonic subdialects as well as in the territory historically inhabited by the Krevin Votians and also that inhabited by the Leivus.

Noun declension also reveals a number of shared morphological features. Replacement of $\bar{e}$-stem plural locative forms with $a$-stem forms, for example, mātās, priedās (SL mātēe 'in mothers', priedès 'in pine trees'), which is typical of some Kurzeme Livonic subdialects around Stende, Strazde, and has been recorded in a small compact area in the Vidzeme Selonic subdialect area: Dzelzava, Sarkani, Patkule, Cesvaine, Lazdona, Prauliena. The form priedam, which is typical of the Vidzeme Livonic subdialects, has been recorded in Lazdona.

The preposition $a z$ and prefix $a z-$, which are typical of the subdialects of northern Kurzeme, have also been recorded in the Selonic subdialects of Graši, L Laudona.

Several parallels between the Livonic dialect and the Vidzeme Selonic subdialects can also be found in verb conjugation. The $-\overline{a j} a-$ stem third-person present tense form mazge (SL mazgā 'wash'), which is typical of the Livonic dialect, has also been identified in the Vidzeme Selonic subdialects of Jumprava and Skriveri. The past tense forms mele, rune (and their variants) (SL meloja 'lied', runāja 'spoke'), which are characteristic of the Kurzeme Livonic subdialects, have also been recorded in the Skrīveri subdialect. 
Forms characteristic of the Livonic subdialect also appear on geolinguistic maps in the subdialects around Preili in Latgale (in Preili, Galēni, Rudzēti, and others), especially generalisation of third-person forms to other persons, e.g., $\bar{e} d$ 'I eat' (SL ẹ $d u$ ), jẹm 'I take' (SL n,ȩmu), aun 'I put on' (SL auju), etc., which has not yet attracted the attention of linguists. Other forms characteristic of the Livonic subdialects found here include the $o$-stem plural accusative forms kuoks 'tree (AccPl)' (SL kuokus), mats 'hair (AccPl)' (SL matus), zieds 'flowers (AccPl)' (SL ziedus), etc. and the first- and second-person singular instrumental pronouns ar man 'with me' (SL ar mani), ar tev 'with you' (SL ar tevi).

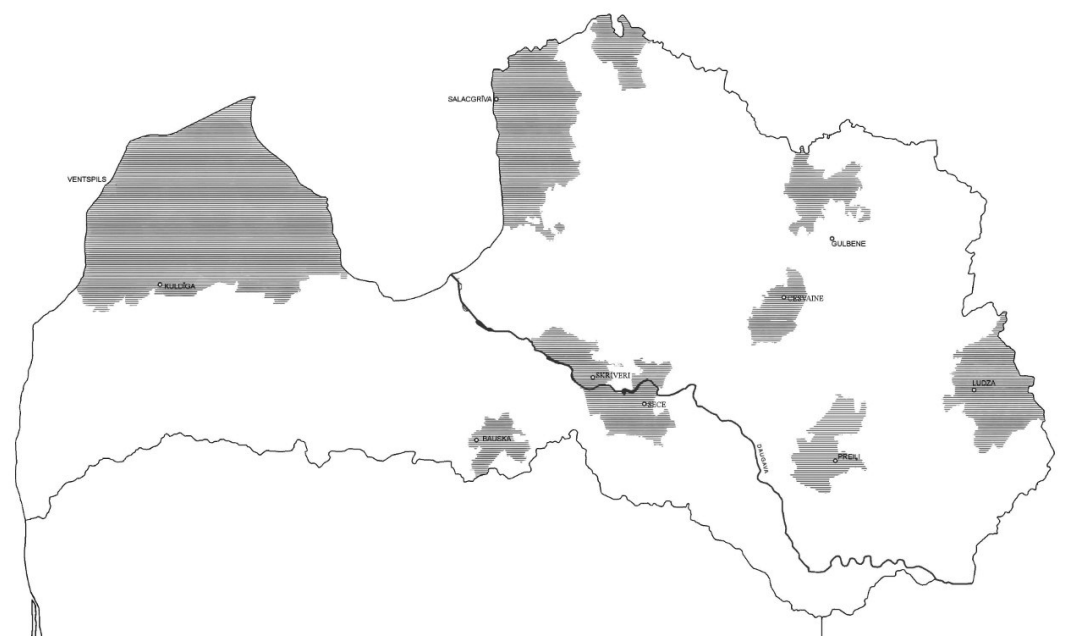

Figure 6. Possible areas of Finnic (phonetic and morphological) influence in Latvian subdialects (according to ALD data). (This map was created by A. Stafecka, its digital version was created by L. Markus-Narvila).

\section{Conclusion}

The dialect material discussed above makes it possible to identify a number of areas in the Livonic and other Latvian dialects, which share phonetic and morphological features with other Latvian subdialects:

1) The areas most frequently showing similarities - the Kurzeme Livonic subdialects and the Selonic subdialects on the right bank of the Daugava River; 
2) a large, compact area in the Kurzeme and Vidzeme Livonic subdialects and the Vidzeme Selonic subdialects;

3) the Kurzeme Livonic subdialects and the Vidzeme Selonic subdialects around Cesvaine and Lazdona;

4) the Vidzeme Livonic subdialects and the Selonic subdialects on the right bank of the Daugava River;

5) the Vidzeme Livonic subdialects and the Selonic subdialects on the right bank of the Daugava River and the Leivu territory (Ilzene, Lejasciems, etc.);

6) the Vidzeme Livonic subdialects, the Selonic subdialects on the right and left banks of the Daugava River, and the Krevin Votian territory in Zemgale along with the subdialects located nearest to it;

7) individual Vidzeme and Zemgale Selonic subdialects and a few subdialects in the Leivu territory (Ilzene, Lejasciems, etc.),

8) Livonic dialects and certain subdialects in Latgale near Preili and its surrounding area, to which linguists have not devoted much attention.

Areas showing possible shared Finno-Ugric influence in Latvian subdialects may be evidence of earlier language contact or may preserve traces of an ancient Finno-Ugric population that lived mixed with the Latvians.

\section{Acknowledgments}

The first volume on morphology of the Latviešu valodas dialektu atlants (Atlas of Latvian Dialects) was prepared as part of the Latvian Council of Science financed project "A New Approach to Geolinguistic Studies of Latvian: Open Data” (Jauna pieeja latviešu valodas geolingvistiskajos pètījumos: atvērtie dati; proj. dir. Dr. philol. Anna Stafecka) with the financial support of the Latvian State Research Project "Letonika: The History, Language, Culture, and Values of Latvia" (VPP "Letonika: Latvijas vēsture, valoda, kultūra, vērtības") No. 3 "Latvian language studies in the context of the 21st century" (Latviešu valodas pétījumi 21. gadsimta zinātnes kontekstā) and published with the financial support of the State Culture Capital Foundation of Latvia. 


\section{References}

Aben, Karl. 1957. Eesti ja liivi laene läti sõnavaras. Emakeele Seltsi aastaraamat 3. 199-216.

Ādamsons, Eduards \& Elga Kagaine. 2000. Vainižu izloksnes vārdnīca. I-II. Rīga: LU Latviešu valodas institūts.

Balode, Sarmīte. 2000. Kalnienas grāmata. Rīga: LU Latviešu valodas institūts.

Balodis, Uldis. 2015. Writing down Lutsi: Creating an Orthography for a South Estonian variety of Latgale. In Andra Kalnača (ed.), Valoda: Nozīme un forma 6 / Language: Meaning and Form 6, 55-67. Rīga: Latvijas Universitātes Akadēmiskais apgāds. https://doi.org/10.22364/vnf.6

Balodis, Uldis. 2019. Expeditions among the Lutsi Estonians and the design of Language Learning Materials. In Sofia Björklöf and Santra Jantunen (eds.), Multilingual Finnic. Language contact and change. (Uralica Helsingiensia 14), 439-478. Helsinki: Suomalais-Ugrilainen Seura. https://doi.org/10.33341/uh.85046.

Balodis, Uldis. 2020. Lutsi kiele lementar. Ludzas igaunu valodas ābece. Rīga, Ludza: LU Lībiešu valodas institūts, Ludzas pilsētas galvenā bibliotēka.

Bielenstein, August. 1892. Atlas der etnologischen Geographie, des heutigen und des phraehistorischen Lettenlands: Beilage zu den Grenzen des lettischen Volksstammes und der lettischen Sprache in der Gegenwart und im 13. Jahrhundert. Die lettischen Dialekte der Gegenwart: Isoglossen - Karte VI. St. Petersburg: Commissionäre der Kaiserlichen Akademie der Wissenschaften.

Breidaks, Antons. 2007 [1972]. Latgalisko izlokšņu prosodijas jautājumi. In Antons Breidaks, Darbu izlase II, 27-39. Riga: LU Latviešu valods institūts, Daugavpils universitāte.

Brejdak, Anton. 2007 [1970]. Vlijanie pribaltijsko-finskih jazykov na latgal'skie govory Ludzenskogo rajona Latvijskoj SSR. In Antons Breidaks, Darbu izlase II, 252-257. Rīga: LU Latviešu valods institūts, Daugavpils universitāte.

Bušmane, Brigita. 2000. Baltijas jūras somu cilmes aizguvumu izplatība latviešu valodas izloksnēs (pēc LVDA materiāliem). Baltistica 35(2). 201-211. https://doi. org/10.15388/baltistica.35.2.570.

Bušs, Ojārs. 2009a. Finno-Ugric borrowings in Latvian (problems of research). In Sturla Berg-Olsen (ed.), The Baltic languages and the Nordic countries. Conference held at the University of Oslo faculty of humanities department of Linguistics and Scandinavian Studies, June 19-20, 2009. Abstracts, 10-12. Oslo: University of Oslo.

Bušs, Ojārs. 2009b. Finno-Ugric borrowings in Latvian (problems of research). In Sturla Berg-Olsen (ed.), The Baltic languages and the Nordic countries. Papers presented at the conference held at the University of Oslo Faculty of Humanities Department of Linguistics and Nordic Studies, June 19-20, 2009, 31-36. Oslo: University of Oslo.

Dravin̄š, Kārlis \& Velta Rūḳe. 1956. Laute und Nominalformen der Mundart von Stenden. 2. Lund: Håkan Ohlssons boktryckeri.

Draviņšs, Kārlis \& Velta Rūḳe. 1958. Verbalformen und undeklinierbare Redeteile der Mundart von Stenden. Lund: Håkan Ohlssons boktryckeri.

Dravniece, Sofija. 2008. Dundagas izloksnes teksti. Rīga: LU Latviešu valodas institūts. 
EH = Endzelīns, Jānis \& Edīte Hauzenberga. 1934-1938. Papildinājumi un labojumi K. Mülenbacha "Latviešu valodas vārdnīcai" I-II. Rīga: Kultūras fonda izdevums. Endzelīns, Jānis. 1951. Latviešu valodas gramatika. Rīga: Latvijas Valsts izdevniecība. Endzelīns, Jānis. 1970. Par latviešu un lībiešu valodas savstarpējo ietekmi. Baltistica 6(1). 7-10. https://doi.org/10.15388/baltistica.6.1.978.

Jansons, Aleksandrs. 1962. Gulbenes rajona toponīmikas jautājumi. In Anna Feldhūne (ed.), Arheologiija un etnogrāfija. IV, 199-204. Rīga: Latvijas PSR Zinātṇu akadēmijas izdevniecība.

Kagaine, Elga. 2004. Lokālie somugrismi latviešu valodas Ziemeḷrietumvidzemes izloksnēs, 58-238. Rīga: LU Latviešu valodas institūts.

Kagaine, Elga. 2008. Vārddarināšanas model̦i ar -apakša un -pakal̦a Ziemeḷrietumvidzemes izloksnēs. In Saulius Ambrazas and Danguolè Mikulènienè (eds.), Kalbos istorijos ir dialektologijos problemos 2, 619-627. Vilnius: Lietuvių kalbos institutas.

Kettunen, Lauri Einari. 1938. Livisches Wörterbuch mit grammatischer Einleitung. Helsinki: Suomalais-Ugrilainen Seura.

Krautmane-Lohmatkina, Lida. 2002. Pope un kaimiņizloksnes. Rīga: LU Latviešu valodas institūts.

LVDA 2013 = Sarkanis, Alberts (ed.). 2013. Latviešu valodas dialektu atlants: fonētika . Rīga: LU Latviešu valodas institūts.

LVDA 2021=Stafecka, Anna (ed.). 2021. Latviešu valodas dialektu atlants: morfologija I. Rīga: LU Latviešu valodas institūts, Zinātne.

LVDA = Morfologijas dalas materiāli [materials for the Atlas of Latvian Dialects. Morphology.]. Materials are stored at the University of Latvia Latvian Language Institute.

ME = Endzelīns, Jānis (ed.). 1923-1932. K[ārḷa] Mülenbacha Latviešu valodas vārdnīca I-IV. Rīga: Izglītības ministrija.

Poiša, Maija. 1985. Vidzemes sēliskās izloksnes. I. Rīga: Zinātne.

Poiša, Maija. 1999. Vidzemes sēliskās izloksnes. II. Rīga: LU Latviešu valodas institūts.

Putniņ̌̌, Eduards. 1985. Svētciema izloksnes apraksts. Rīga: Zinātne.

Rağe, Silvija. 2003 [1981]. Zum Einfluss des Etnischen und Livischen auf die Lettischen Mundarten. In Silvija Raǵe, Darbu izlase, 268-270. Rīga: LU Latviešu valodas institūts.

Rudzīte, Marta. 1964. Latviešu dialektologija. Rīga: Latvijas Valsts izdevniecība.

Rudzìte, Marta. 1994. Latviešu un lībiešu valodas savstarpējā ietekme. In Kersti Boiko (ed.), Lībieši, 288-319. Rīga: Zinātne.

Rudzīte, Marta. 1993. Latviešu valodas vēsturiskā fonētika. Rīga: Zvaigzne.

Rūḳe-Draviṇa, Velta. 2017 [1940]. Kurzemes un Vidzemes lībiskais apgabals. In Velta Rūḳe-Draviņa, Darbu izlase, 405-461. Rīga: LU Latviešu valodas institūts.

Stafecka, Anna. 2014. Baltic and Finnic Linguistic Relations Reflected in the Geolinguistic Studies of the Baltic Languages. Eesti ja soome-ugri keeleteaduse ajakiri. Journal of Estonian and Finno-Ugric Linguistics 5(2), 117-137. https://doi. org/10.12697/jeful.2014.5.2.06.

Thomsen, Vilhelm. 1890. Berøringen mellem de finske og de baltiske (litauisk-lettiske) Sprog, en sproghistorisk Undersøgelse. København: B Lunos Bogtryk. 
Vaba, Lembit. 1997. Uurimusi läti-eesti keelesuhetest. Tallinn, Tampere: Eesti Keele Instituut, Tampereen Yliopiston suomen kielen ja yleisen kielitieteen laitos.

Winkler, Eberhard. 1997. Krewinisch. Zur Erschließung einer ausgestorbenen ostseefinnischen Sprachform. Wiesbaden: Harrassowitz Verlag.

Zemzare, Daina. 2017 [1940]. Valodas liecības par Lejasciema novadu. In Daina Zemzare. Darbu izlase, 30-173. Rīga: LU Latviešu valodas institūts.

Zeps, Valdis J. 1962. Latvian and Finnic Linguistic Convergences. (Uralic and Altaic Series 9). Bloomington: Indiana University Publications.

\begin{abstract}
Kokkuvõte. Anna Stafecka: Läänemeresoome mõju võimalikud jäljed läti murrakute foneetikas ja morfoloogias. Artikkel käsitleb läänemeresoome ja läänemeresoomepäraste joonte maa-alalist levikut läti murretes. Läti murdeainestik, mida on selle uurimuse jaoks analüusitud, näitab, et foneetilise ja morfoloogilise eripära põhjal on võimalik määratleda mitu sellist mõjuala: liivipärased murded, teatud seeli murrakud Daugava jõe mõlemal kaldal, teatud Kirde-Läti Alūksne ja Gulbene ümbruse murrakud ajaloolisel leivu alal ning mõned semgali murrakud Bauska ja Vecsaule lähistel, kus kunagi elasid kreevini vadjalased. Sõnalõppude lühenemist ja kolmanda isiku verbivormide üldistumist on üsna regulaarselt märgitud ka Latgales Preiḷi ümbruse murrakutes. Vähem on selliseid andmeid Ida-Latgalest Ludza eestlaste ehk lutside kunagistelt asualadelt. Siiski on seal lutsi mõju nähtav kohalike murrakute toonisüsteemis.
\end{abstract}

Märksõnad: läti murded, läänemeresoome keeled, dialektoloogia, geolingvistika, keelekontakt 